\title{
The impacts of ultrasound-assisted protein hydrolysate coating on the quality parameters and shelf life of smoked bonito fillets stored at $4 \pm 1^{\circ} \mathrm{C}$
}

\section{Ultrason destekli protein hidrolizatı kaplamanın tütsülenerek $4 \pm 1^{\circ} \mathrm{C}$ 'de depolanan palamut filetolarının kalite parametreleri ve raf ömrü üzerine etkileri}

\author{
Gülsüm Balçık Mısır ${ }^{1 *}$ • Serkan Koral2
}

${ }^{1}$ Central Fisheries Research Institute, Vali Adil Yazar Street, No:14, Kasustu, Trabzon, Turkey

2 Katip Çelebi University, Faculty of Fisheries, Fish Processing Technology Department, Çiğli, İzmir, Turkey

(D) https://orcid.org/0000-0001-8675-8768

(D) https://orcid.org/0000-0001-7424-2481

\section{How to cite this paper:}

Balçık Mısır, G. \& Koral, S. (2021). The impacts of ultrasound-assisted protein hydrolysate coating on the quality parameters and shelf life of smoked bonito fillets stored at $4 \pm 1^{\circ} \mathrm{C}$. Ege Journal of Fisheries and Aquatic Sciences, 38(4), 427-435. DOI: 10.12714/egejfas.38.4.04

\begin{abstract}
Innovative bioactive protein hydrolysates (PH), produced from Rainbow trout (Oncorhynchus mykiss W., 1792) by-products, were used as a coating on smoked fillets of bonito (Sarda sarda) for extension of the quality and shelf life during chilled storage for 60 days. Three fillet groups were prepared as control group without coating (CG), normal hydrolysate coated group (NHCG), and ultrasound-assisted hydrolysate coated group (UHCG). Total volatile basic nitrogen (TVB-N) and TBA values exceeded the acceptable limits on the 39th and 33rd days for CG respectively; 60th day for NHCG and UHCG. However TBA of UHCG was significantly lower than NHCG. Total aerobic mesophilic bacteria (TAMB) and total aerobic psychrophilic bacteria (TAPB) loads reached $6.32 \pm 0.06$ and $7.30 \pm 0.12 \mathrm{log}$ cfu/g for $C G$ on the 39th day. TAMB and TAPB values of NHCG and UHCG have remained within the limits of consumable until the end of the storage. PH coatings prolonged the storage of fillets by delaying chemical, physical, and microbial degradation. Results showed that ultrasound-assisted PH could be used as a coating for smoked bonito at refrigerated conditions, delaying oxidation and microbial degradation.

Keywords: Bioactive coatings, protein hydrolysate, smoked fish fillet, ultrasound, food preservation

Öz: Gökkuşağı alabalığı (Onchorhynchus mykiss W., 1792) yan ürünlerinden üretilmiş yenilikçi biyoaktif protein hidrolizatı (PH), tütsülenerek 60 gün boyunca soğuk depolanan palamut filetolarının kalite ve raf ömrünü uzatmak amacıyla kaplama olarak kullanıımışır. Kaplamasız kontrol grubu (CG), normal hidrolizat kaplı grup (NHCG) ve ultrason destekli hidrolizat kaplı grup (UHCG) olarak üç fileto grubu hazırlanmış̧ır. CG için toplam uçucu bazik nitrojen (TVB-N) ve TBA değerleri, kabul edilebilirlik sınırlarını sırasıyla 39. ve 33. günde; NHCG ve UHCG için ise 60. günde aşmıştır. Ancak UHCG'un TBA değeri NHCG'dan önemli ölçüde daha düşüktür. CG'na ait toplam aerobik mezofilik bakteri (TAMB) ve toplam aerobik psikrofilik bakteri (TAPB) yükleri 39. günde sırasıyla $6,32 \pm 0,06$ ve 7,30 $\pm 0,12$ log kob/g'a ulaşmıştı. Bu değerler NHCG ve UHCG için depolamanın sonuna kadar tüketilebilirlik sınırları içinde kalmışıı. PH kaplamalar kimyasal, fiziksel ve mikrobiyal bozunmayı geciktirerek filetoların depolama süresini uzatmıştır. Sonuçlar ultrason destekli PH'nın, oksidasyon ve mikrobiyal bozunmayı geciktirerek, soğuk koşullarda depolanan tütsülenmiş palamut için kaplama olarak kullanılabileceğini göstermiştir.

Anahtar kelimeler: Biyoaktif kaplama, protein hidrolizatı, tütsülenmiş balık filetosu, ultrason, gıda muhafazası
\end{abstract}

\section{INTRODUCTION}

FAO authority stated, "Food loss and waste is a big challenge of our time". Food losses and waste occurs at all stages from farm to table including harvesting, transferring, processing, and storage. With the reduction of all these losses and wastes, productivity increases, more food can be supplied to people, and reduced economic and environmental problems such as energy and water are wasted (FAO, 2020).

Fish is an extremely perishable food, this spoilage occurs at every stage of the process from harvest to consumption, and rapid quality losses are experienced. This deterioration occurs not only how the fish is treated but by the biological reactions that occur in its structure and the metabolic activities of the bacteria (Lougovois and Kyrana, 2005). Also, high rate of unsaturated fatty acids is one of the leading causes of degradation by oxidation. As a result, loss of nutritional quality properties such as safety, color, flavor, and texture and shortening the shelf life of the fish (Sone et al., 2019). As a result, it needs particular care to be taken from harvesting and all necessary steps to preserve quality nutritional properties and decrease losses and waste.

A large part of the fish produced in the world is processed and presented for consumption. The smoking process not only prolongs the shelf life but also helps to improve the organoleptic characteristics of fish. It has been reported that the combined effects of the salt in the brine, the high temperature and the antibacterial and antioxidant compounds in the sawdust composition are responsible for the protection compared to non-smoked products. Drying the fish surface by 
the effect of the process also decreases the water activity (aw), resulting in increased inhibition of bacterial growth (Lerfall and Hoel, 2020). Although the above advantages, smoked fish are among semi-preserved products and always carry a risk for quality assurance (Kramarenko et al., 2016). To meet the consumer's demand for quality and prevent economic losses, the producers try to find innovative methods and new applications to produce safe-to-eat products with high quality and extended shelf life.

In recent years, the use of certain natural molecules such as tocopherols, ascorbic acid, plant extracts in the storage of such products has great potential. Edible coatings have been tried with an overall goal of improving safety, quality, and extend shelf life. The application of coatings achieves this with the corresponding functionality through the surface of the product. There is an increasing trend as artificial materials changing towards natural-based and eco-friendly alternatives on coating materials. PH's from marine sources has been reported to possess strong protection properties for the quality of fish (Hajfathalian et al., 2020). Especially protein hydrolysates produced from a by-product of aquatic organisms allow utilizing the lost and highly protein-rich materials as natural sources. The application of innovative technologies such as high hydrostatic pressure, irradiation, ultrasound, filtration, plasma technology, pulsed electric field, gamma irradiation, supercritical fluid extrusion, etc., can modify the protein structure and functional properties. Among these technologies, ultrasound technology modifies the enzymatic hydrolysis and could increase extraction yields and enhance the hydrolysate properties. Ultrasound is a novel technology is a safe, non-toxic, eco-friendly and easy to use. It can be divided into two categories; high frequency, low energy diagnostic ultrasound, low frequency, high energy power ultrasound, and have shown significant improvements in the food industry in the analysis and the modification of food products. Significant changes occur in physicochemical characteristics of food under the power ultrasonic frequency (between $16 \mathrm{kHz}$ to $100 \mathrm{kHz}$ ). Ultrasonic waves cause gas dissolution and cavitation that result in physical, mechanical, or chemical, biochemical effects on modifying the product properties compared to conventional methods (Zink et al., 2016). One application is extracting on the recovery of protein and bioactive compounds (Wen et al., 2018). It could significantly improve the enzymatic hydrolysis and properties of proteins such as potential free radical-scavenging activities and capability of lipid oxidation-reduction (Balcik Misir and Koral, 2019a). But the ultrasound treatments still need new research to find out the ultrasound technology's effectiveness on food properties. Several studies have been achieved in the production of ultrasound-assisted $\mathrm{PH}$ from plant and animal origin raw materials and determining characteristics of the final products such as biochemical composition, molecular structure, amino acid composition, functional properties, antioxidant and antimicrobial activities. But very limited reported researches exist in investigating the effects of ultrasound-assisted hydrolysates coatings on shelf life and quality parameters of smoked fish.

Atlantic bonito (Sarda sarda Bloch, 1793), a fusiform fish species belonging to the Scombroid family, has a high market value globally and Turkey. It is a good source of food with high protein and fat contents (average $20.16 \mathrm{~g} / 100 \mathrm{~g}$ and $8.4 \%$, respectively) including reasonable amounts of eicosapentaenoic acid (EPA) and docosahexaenoic acid (DHA) in a range of $252.0-1169.1 \mathrm{mg} / 100 \mathrm{~g}$ and $712.1-$ $3324.1 \mathrm{~g} / 100 \mathrm{~g}$, respectively, (Balçik Misir et al., 2014). But high rate of unsaturated fatty acids causes deterioration and degradation by oxidation of bonito flesh.

In this study, smoked bonito fillets were coated with $\mathrm{PH}$ produced from rainbow trout by-products (not include viscera) enzymatically normal and ultrasound-assisted. $\mathrm{PH}$ was produced and characterized biochemically, functionally, and structurally in a previous study (Balcik Misir and Koral, 2019a). Coatings were applied by the dipping method and coated fillets were stored at $4 \pm 1^{\circ} \mathrm{C}$. To determine the impact of coatings on fillet's quality and shelf life, physicochemical properties and bacterial counts of coated fillets were analyzed during 60 days.

\section{MATERIAL AND METHODS}

Fish protein hydrolysates; Normal hydrolysate $(\mathrm{NH})$ was produced from rainbow trout by products and characterized previously. The production was conducted briefly by using Alcalase $2.4 \mathrm{~L}$ with enzyme/substrate ratio of $0.5 \%, \mathrm{pH} 8$, for $1 \mathrm{~h}$ at $60^{\circ} \mathrm{C}$. The same conditions were used for ultrasound-assisted $\mathrm{PH}$ production. A probe-type ultrasound equipment (Sonics Vibra cell, USA, tapered micro tip, $142 \times 6 \mathrm{~mm}$ ) with $40 \%$ ultrasonic amplitude, pulse duration of $10 \mathrm{~s}$ on- time; $20 \mathrm{~s}$ off-time was applied during the production. $\mathrm{NH}$ contains $86.40 \%$ protein, $0.05 \%$ lipid, $1.36 \%$ moisture, and $6.25 \%$ ash, with the degree of hydrolysis 25.29 $\%$. Ultrasound-assisted hydrolysate (UH) contains $86.75 \%$ protein $0.05 \%$ lipid, $2.10 \%$ moisture, and $5.95 \%$ ash with the degree of hydrolysis $23.67 \%$. Copper (II) ion-reducing antioxidant capacities (CUPRAC) were $230.23 \mu \mathrm{M}$ Trolox®/mg mixture and $244.89 \mu \mathrm{M}$ Trolox®/mg mixture for $\mathrm{NH}$ and $\mathrm{UH}$, in order. Iron (III) ion-reducing antioxidant power (FRAP) antioxidant activities were 12.161 $\mu \mathrm{M}$ FeSO4.7H2O/mg mixture and $13.75 \mu \mathrm{M}$ FeSO4.7H2O/mg mixturefor $\mathrm{NH}$ and $\mathrm{UH}$, respectively (Balcik Misir and Koral, 2019a). Food-grade glycerol; (99.96\% purity W252506, Sigma-Aldrich) at $20 \%$ (w/w, based on biopolymer content) was purchased from Sigma Aldrich (Steinheim, Germany) and used as a plasticizer. All other chemicals, solvents used in this work were of analytical grade.

Fish, thirty individuals of fresh bonito weighing $15.25 \mathrm{~kg}$, were purchased from a local fish market in Trabzon, Turkey. 
The bonitos were immediately stored in ice in polystyrene boxes and delivered to the laboratory. The average weight and length of the whole fish were $503.75 \pm 45.67 \mathrm{~g}$ and $36.20 \pm 0.91 \mathrm{~cm}$, respectively.

Smoking material; beechwood sawdust (purchased from a local supplier).

Smoking, coating, and storage of bonito fillets in the cold $\left(+4 \pm 1^{\circ} \mathrm{C}\right)$ storage conditions; Bonitos were eviscerated, filleted, and washed, then drained for thirty minutes. Drained fillets were brined before smoking. Brining was carried out by immersing. The fillets were immersed in $10 \%$ sodium chloride $(\mathrm{NaCl})$ solution for $1 \mathrm{~h}$ at $2^{\circ} \mathrm{C}$ for brining. After that, fillets were washed and drained again, then placed on the grills of the smoking kiln.

Smoking kiln specifications; A conventional smoking kiln (TERMAL Laboratuvar Aletleri, Istanbul, Turkey) made of stainless chrome with dimensions $120 \times 80 \times 80 \mathrm{~cm}$ (height $\mathrm{x}$ width $x$ depth). On-board electronic thermostat (adjustable between $\left.0-260^{\circ} \mathrm{C}\right)$ and humidity meter $(0-100 \%)$ were available. For the heating of the kiln, $A$ hidden resistance $(220$ V) was placed between two floors for heating. A separate oven was used to produce smoke and mouthed to the oven with a $13 \mathrm{~cm}$ diameter chrome pipe.

Smoking process conditions; The hot smoking process was performed according to Koral (2006). Firstly the fillets on the smoking kiln grills were dried in the smoking kiln for 30 $\mathrm{min}$, at $30^{\circ} \mathrm{C}$ and then the kiln temperature was increased to $60^{\circ} \mathrm{C}$ and the process was continued at this temperature for $45 \mathrm{~min}$. After that the temperature was allowed to reach $90^{\circ} \mathrm{C}$, and the fillets were kept at this temperature for another 30 minutes. Then, the smoking process was completed, and the smoked fillets were allowed to cool at room temperature $\left(22 \pm 2^{\circ} \mathrm{C}\right)$.

Preparation and application of the coatings materials; $\mathrm{NH}$ and $\mathrm{UH}$ were dissolved in distilled water $(10 \% \mathrm{w} / \mathrm{w})$, and glycerol was added (2:1 protein/glycerol) as plasticizer $(\mathrm{pH}$ was adjusted to 7 with $\mathrm{HCl}$ or $\mathrm{NaOH}$ ). Solutions were stirred slowly in a water bath (Daihan, Digital Precise Water Bath, WB, 06, Philippines) for $15 \mathrm{~min}$ at $60^{\circ} \mathrm{C}$ (Rodriguez-Turienzo et al., 2011). The coating materials were applied on one side of the fish with a silicone brush and left to stand for 5 minutes. After that, the same process was repeated for the other side. CG was prepared as uncoated. The fillets were placed in styrofoam plates individually, covered with stretch film for each day of analysis. Physical, chemical, and microbiological analyses were performed on the fresh fish and, $1^{\text {st }}, 6^{\text {th }}, 12^{\text {th }}$, $16^{\text {th }}, 21^{\text {st }}, 33^{\text {th }}, 39^{\text {th }}, 50^{\text {th }}$, and $60^{\text {th }}$ days of storage. For the $0^{\text {th }}$ day analysis, samples $(n=6$ different fillets; $n=2$ for each group) were kept at $-80^{\circ} \mathrm{C}$ until analysis. The rest of the fillets ( $n=54$ different fillets; $n=2$ fillets for each group) was stored at $4 \pm 1^{\circ} \mathrm{C}$ for analysis. Before each analysis, the film was taken off from the plates, and the fillets were homogenized with a knife by cutting into small particles.

\section{Measurement of salt, aw, $\mathrm{pH}$, and color}

The salt content was determined by the Mohr method. According to the procedure, the aliquot was titrated with $0.1 \mathrm{~N}$ silver nitrate, and the amount of salt was calculated (Rohani et al., 2010). aw was measured with Aqualab 3TE (0.100$1.000 \pm 0.003$, Aqualab, Decagon Devices, Pullman, Washington, USA) brand device at $25^{\circ} \mathrm{C}\left( \pm 0.2^{\circ} \mathrm{C}\right)$. pH was measured with a probe-type $\mathrm{pH}$ meter (Mettler-Toledo AG, Seven Compact 8603 N, Sweden) with the procedure given by Koral (2012). Konica Minolta Colorimeter (CR 10, Tokyo, Japan) was used for color measurement of the coated fillets. The instrument was standardized with the standard white plate. CIE color table was used for evaluation. Three different points of the surface of two fish fillets were taken for the measurement.

Indicators of fish degradation and resistance to fat oxidation

Deterioration and fat oxidative stability of fillets during storage were assessed in TVB-N, TMA, and TBA analysis. The method described by Lücke and Geidel (1935) was used for TVB-N analysis. TBA analysis was carried out with the method used by Tarladgis et al. (1960). TMA analysis was done according to Boland and Paige (1971). TVB-N, TBA, and TMA analyses were performed as described previously by Balcik Misir and Koral (2019b). All experiments were performed in triplicate.

\section{Microbiological analysis}

The surface plate method was used for enumeration. All counts were expressed as log CFU/g and performed in triplicate.

Total aerobic mesophilic bacteria (TAMB) and total aerobic psychrophilic bacteria (TAPB) counts

Standard plate count agar (PCA, Cat No. 105463, Merck, Darmstadt, Germany) was used for TAMB and TAPB. The methods determined by Bell et al. (2005) were applied for TAMB and TAPB analysis.

\section{Yeast, mold, and coliform count}

Potato dextrose agar (Cat. No: 1.10130.500, Merck, Darmstadt, Germany) was used for yeast and mold count, and violet bile agar (Cat. No: 1.01406.0500, Merck, Darmstadt, Germany) was used for the coliform count. The procedure was followed, explained by Bell et al., (2005).

All experiments were performed in triplicate.

\section{Data analysis}

All data analyses were done in triplicates, and means were compared statistically with Analysis of variance (oneway ANOVA), in case of significant differences, Tukey and 
Mann Whitney $U$ test (data not provided in the normality of assumptions) were applied with the program named "JMP 5.0.1" (SAS Institute. Inc. USA) and SPSS 18.0 (SPSS Inc., Chicago, IL) (Sokal and Rohlf, 1987). A significance level of 95\% $(\mathrm{P}<0.05)$ was used throughout the analysis.

\section{RESULTS AND DISCUSSION}

\section{Salt, aw, pH and color}

Salt contents of smoked, and coated fillets were analyzed and calculated as $6.45 \%, 7.60 \%$ and $7.88 \%$, for CG, NHCG and UHCG, respectively. Codex Alimentarius (2013) stated that the salt concentration in the aqueous solution should be at least $5 \%$ to ensure completely effective protection at temperatures from 3 to $10^{\circ} \mathrm{C}$. As it can be seen in Table 1 , the initial $a_{w}$ of the fresh bonito fillet was 0.993. A similar $a_{w}$ value (0.994) was measured by Koral and Köse (2018), for the same species. In the current study, fluctuations have occurred in all groups' aw values during storage. It was measured above the limiting level of this parameter to ensure microbial stability because it is generally accepted that no microbial growth will occur at $a_{w}<0.66$ (Castañeda-López et al., 2021). Decreasing of aw value was assumed as a result of the application of salting and drying processes due to the nature of smoking technology. It has been determined that salt substitution and drying process decreases the $a_{w}$ of foods (Pedro and Nunes, 2019). The acidity level of the fillets was determined by the $\mathrm{pH}$ measurement. The initial $\mathrm{pH}$ of the smoked fillet was $6.21 \pm 0.03$. It was decreased in each group on the first day, and the differences between CG and NHCG and UHCG were not significant $(p<0.05)$. It fluctuated for each group, but the general trends were reducing during the storage. No significant differences were observed between NHCG and UHCG except the 6th day of storage $(p>0.05)$ (Table 1). This similarity can be attributed to the $\mathrm{pH}$ values of the two coatings that ultrasound treatment hadn't affected the $\mathrm{pH}$ of the PH (Balcik Misir and Koral 2019a). Several researchers have explained that the $\mathrm{pH}$ of smoked fish can be affected by some factors such as used fish species, smoking material, salting process, smoking procedure, and temperature of the process (Muñoz, et al., 2020; Jimenez et al., 2020). The decreasing of the $\mathrm{pH}$ during storage was attributed to the salt content which has been said to have a highly significant linear decreasing effect on the $\mathrm{pH}$, which was explained by the increase of the ionic strength of the solution inside of the cells (Leroi and Joffraud, 2000). This is confirmed by the present results. Color is one of the most important elements that influence consumer acceptance of food products. Coating materials affected the color of smoked fillets (Table 1); CG differed significantly $(p<0.05)$ from coated fillets. Decreasing values have been experienced during the storage in this group. The color of UHCG was brighter and preserved the original color of fillets longer than CG and NHCG. $L^{*}$ value, which represents the lightness and varies from 0 (black) to 100 (white), was measured as 45.08 for fresh bonito fillets and increased in all groups after smoking. However, NHCG and UHCG have higher $L^{*}$ values than CG. $L^{*}$ values of $\mathrm{CH}$ have decreased during storage and measured as 41.03 on the 39th day of storage, where it sensibly fell below the consumable limit. $L$ * values of NHCG and UHCG increased on the 1st day of storage and then decreased in the following days. Decreased values of $L^{*}$ demonstrated that fillets have become pale and darker. However, the barrier formed by the coating materials against environmental oxygen, other gases and moisture, made NHCG and UHCG more attractive than CG. Karnjanapratuma and Benjakul (2020) had determined the impact of the ultrasound-assisted process (UAP) on the yield and characteristics of Asian bullfrog skin gelatin. In their research, ultrasonication caused increased $L^{*}$ value, representing the lighter color of the gelatin. $a^{*}$ value of the $C G$ had increased during the storage and reached the maximum value on the $39^{\text {th }}$ day (16.68). Although $a^{*}$ values of NHCG and UHCG showed an increasing trend during the storage, they were lower than CG. Increasing $a^{*}$ value means increasing the redness in the color of fillets. The previous researchers also had similar results in their studies that mean generally smoking effect increase the redness of the fish fillets (Lerfall, and Hoel, 2021; Valø et al., 2020). Having statistically different $L^{*}, a^{*}$, and $b^{*}$ values from other groups, UHCG has prevented the color of fillets more effectively. The structural changes produced by ultrasonication during protein hydrolysate production might have influenced the color parameters.

Table 1. Changes in $\mathrm{aw}, \mathrm{pH}$ and color $\left(\mathrm{L}^{*}, \mathrm{a}^{*}, \mathrm{~b}^{*}\right)$ parameters of smoked bonito fish preserved in cold storage $\left(4 \pm 1^{\circ} \mathrm{C}\right)$

\begin{tabular}{|c|c|c|c|c|c|c|}
\hline Days & Sample & $a_{w}$ & $\mathrm{pH}$ & $L^{*}$ & $a^{*}$ & $\mathbf{b}^{*}$ \\
\hline \multirow[t]{2}{*}{0} & Fresh bonito & $0.993 \pm 0.001$ & $6.21 \pm 0.03$ & $45.08 \pm 0.32$ & $11.09 \pm 0.28$ & $21.10 \pm 0.23$ \\
\hline & CG & $0.980 \pm 0.001 \mathrm{a}_{\mathrm{A}}$ & $5.43 \pm 0.03^{a_{A}}$ & $45.10 \pm 0.22^{\mathrm{a}_{\mathrm{A}}}$ & $13.40 \pm 0.08^{\mathrm{a}_{\mathrm{A}}}$ & $24.75 \pm 0.13^{a_{A}}$ \\
\hline \multirow[t]{3}{*}{1} & NHCG & $0.977 \pm 0.000^{a_{A}}$ & $5.45 \pm 0.01 \mathrm{a}_{\mathrm{A}}$ & $45.93 \pm 0.21 \mathrm{~b}_{\mathrm{A}}$ & $12.23 \pm 0.05^{\mathrm{b}} \mathrm{A}$ & $23.68 \pm 0.16^{\mathrm{b}} \mathrm{A}$ \\
\hline & UHCG & $0.977 \pm 0.002^{\mathrm{a}_{\mathrm{A}}}$ & $5.39 \pm 0.04 \mathrm{a}_{\mathrm{A}}$ & $46.28 \pm 0.13^{b} A$ & $12.28 \pm 0.22^{\mathrm{b}} \mathrm{A}$ & $23.50 \pm 0.08^{b} \mathrm{~A}$ \\
\hline & CG & $0.975 \pm 0.001 \mathrm{a}_{\mathrm{B}}$ & $5.31 \pm 0.02^{a_{B}}$ & $42.93 \pm 0.13^{a_{B}}$ & $14.23 \pm 0.15^{\mathrm{a}}{ }_{\mathrm{B}}$ & $24.48 \pm 0.14^{\mathrm{a}_{\mathrm{A}}}$ \\
\hline \multirow[t]{3}{*}{6} & NHCG & $0.977 \pm 0.001 \mathrm{a}_{\mathrm{A}}$ & $5.64 \pm 0.01^{b_{B}}$ & $46.15 \pm 0.24 \mathrm{~b}_{\mathrm{A}}$ & $13.90 \pm 0.14^{b}{ }_{B}$ & $23.18 \pm 0.18^{b} B$ \\
\hline & UHCG & $0.972 \pm 0.001 \mathrm{~b}_{\mathrm{B}}$ & $5.69 \pm 0.01 c_{B}$ & $47.15 \pm 0.10 c_{B}$ & $12.73 \pm 0.10^{b_{B}}$ & $22.20 \pm 0.12^{b} B$ \\
\hline & CG & $0.977 \pm 0.001^{\mathrm{a}_{\mathrm{C}}}$ & $5.42 \pm 0.01 \mathrm{a}_{\mathrm{A}}$ & $42.97 \pm 0.25^{\mathrm{a}} \mathrm{B}$ & $14.87 \pm 0.15^{\mathrm{a}} \mathrm{C}$ & $24.07 \pm 0.06^{\mathrm{a}} \mathrm{B}$ \\
\hline \multirow[t]{2}{*}{12} & NHCG & $0.979 \pm 0.001 \mathrm{a}_{\mathrm{A}}$ & $5.53 \pm 0.01^{\mathrm{b}} \mathrm{C}$ & $45.23 \pm 0.06^{b_{B}}$ & $13.83 \pm 0.06^{\mathrm{b}} \mathrm{B}$ & $23.02 \pm 0.15^{b_{B}}$ \\
\hline & UHCG & $0.974 \pm 0.001 \mathrm{~b}_{\mathrm{A}}$ & $5.51 \pm 0.06^{b} \mathrm{c}$ & $47.10 \pm 0.06^{\mathrm{a}_{\mathrm{B}}}$ & $13.20 \pm 0.17 c^{c} \mathrm{c}$ & $21.47 \pm 0.12^{c} \mathrm{C}$ \\
\hline
\end{tabular}


Table 1. Continued

\begin{tabular}{|c|c|c|c|c|c|c|}
\hline \multirow[b]{2}{*}{16} & CG & $0.975 \pm 0.001 \mathrm{a}_{\mathrm{B}}$ & $5.26 \pm 0.01{ }^{\mathrm{a}} \mathrm{C}$ & $42.23 \pm 0.15^{\mathrm{a}} \mathrm{C}$ & $15.20 \pm 0.10^{a_{D}}$ & $23.83 \pm 0.29 \mathrm{a}_{\mathrm{c}}$ \\
\hline & NHCG & $0.974 \pm 0.002^{\mathrm{b}} \mathrm{A}$ & $5.39 \pm 0.03^{b} \mathrm{D}$ & $44.53 \pm 0.29{ }^{b} \mathrm{c}$ & $13.30 \pm 0.34^{b} c$ & $22.47 \pm 0.06^{b} c$ \\
\hline \multirow{4}{*}{21} & UHCG & $0.969 \pm 0.000^{\circ} \mathrm{C}$ & $5.35 \pm 0.02^{\mathrm{b}} \mathrm{A}$ & $45.27 \pm 0.23^{c} c$ & $12.87 \pm 0.42^{b_{B}}$ & $21.23 \pm 0.15^{c_{C}}$ \\
\hline & CG & $0.976 \pm 0.001 \mathrm{a}_{\mathrm{BC}}$ & $4.91 \pm 0.04 \mathrm{a}^{\mathrm{a}}$ & $41.65 \pm 0.177^{a} \mathrm{D}$ & $15.48 \pm 0.18 c_{E}$ & $23.45 \pm 0.08^{a_{D}}$ \\
\hline & NHCG & $0.966 \pm 0.001 b_{B}$ & $4.76 \pm 0.06^{b} \mathrm{E}$ & $44.28 \pm 0.08^{b} \mathrm{D}$ & $14.00 \pm 0.14 \mathrm{~b}_{\mathrm{B}}$ & $22.95 \pm 0.06^{b_{B}}$ \\
\hline & UHCG & $0.966 \pm 0.001 b_{D}$ & $4.80 \pm 0.02^{\mathrm{b}} \mathrm{D}$ & $45.15 \pm 0.06 c_{C}$ & $13.45 \pm 0.06^{\mathrm{a}} \mathrm{c}$ & $22.63 \pm 0.16 c_{D}$ \\
\hline \multirow{3}{*}{33} & CG & $0.976 \pm 0.001 \mathrm{a}_{\mathrm{BC}}$ & $4.95 \pm 0.01 \mathrm{a}_{\mathrm{D}}$ & $41.28 \pm 0.10^{\mathrm{a}_{\mathrm{E}}}$ & $16.53 \pm 0.10^{a_{F}}$ & $23.65 \pm 0.31 \mathrm{a}_{\mathrm{E}}$ \\
\hline & NHCG & $0.972 \pm 0.0011^{\mathrm{b}} \mathrm{A}$ & $5.09 \pm 0.03^{b} F$ & $44.18 \pm 0.19^{b} \mathrm{E}$ & $14.30 \pm 0.08^{\mathrm{b}} \mathrm{D}$ & $22.35 \pm 0.10^{\mathrm{b}} \mathrm{c}$ \\
\hline & UHCG & $0.973 \pm 0.002^{\mathrm{b}}{ }_{\mathrm{AB}}$ & $5.06 \pm 0.02^{\mathrm{b}} \mathrm{E}$ & $44.88 \pm 0.13 c_{D}$ & $14.25 \pm 0.06^{b_{D}}$ & $22.02 \pm 0.19 c_{B}$ \\
\hline \multirow{3}{*}{39} & CG & $0.972 \pm 0.001 \mathrm{a}_{\mathrm{D}}$ & $4.97 \pm 0.02^{\mathrm{a} D}$ & $41.03 \pm 0.11 \mathrm{a}_{\mathrm{F}}$ & $16.68 \pm 0.19 \mathrm{a}_{\mathrm{F}}$ & $23.88 \pm 0.13^{a_{C}}$ \\
\hline & NHCG & $0.973 \pm 0.001 \mathrm{a}_{\mathrm{A}}$ & $4.83 \pm 0.04^{\mathrm{b}} \mathrm{E}$ & $43.63 \pm 0.29 \mathrm{~b}_{\mathrm{F}}$ & $14.73 \pm 0.13^{\mathrm{b}} \mathrm{E}$ & $22.10 \pm 0.14 b_{D}$ \\
\hline & UHCG & $0.974 \pm 0.001 \mathrm{a}_{\mathrm{A}}$ & $4.85 \pm 0.02^{\mathrm{b}} \mathrm{D}$ & $44.45 \pm 0.18^{c_{E}}$ & $14.45 \pm 0.13^{b_{E}}$ & $22.75 \pm 0.15 c_{D}$ \\
\hline \multirow{3}{*}{50} & CG & * & * & * & * & * \\
\hline & NHCG & $0.973 \pm 0.0011_{\mathrm{A}}$ & $4.88 \pm 0.03^{a_{E}}$ & $43.17 \pm 0.13^{a_{F}}$ & $15.23 \pm 0.06 \mathrm{a}_{\mathrm{F}}$ & $21.63 \pm 0.06^{a_{E}}$ \\
\hline & UHCG & $0.971 \pm 0.001 \mathrm{a}_{\mathrm{A}}$ & $4.87 \pm 0.02^{\mathrm{a}} \mathrm{D}$ & $44.00 \pm 0.10^{\mathrm{b}} \mathrm{F}$ & $15.07 \pm 0.15^{b} \mathrm{~F}$ & $21.13 \pm 0.12^{b_{E}}$ \\
\hline \multirow{3}{*}{60} & CG & * & * & * & * & * \\
\hline & NHCG & $0.968 \pm 0.001 \mathrm{a}_{\mathrm{B}}$ & $4.92 \pm 0.03^{a_{E}}$ & $43.02 \pm 0.144^{a_{F}}$ & $15.58 \pm 0.14 \mathrm{a}_{G}$ & $21.78 \pm 0.13^{a_{E}}$ \\
\hline & UHCG & $0.970 \pm 0.001 \mathrm{a}_{\mathrm{A}}$ & $4.91 \pm 0.02^{\mathrm{a}} \mathrm{D}$ & $43.88 \pm 0.13^{b} G$ & $15.30 \pm 0.10^{b} G$ & $21.34 \pm 0.16^{b}$ \\
\hline
\end{tabular}

Different lowercase letters $(a, b, c)$ in the same column indicate the difference between the groups on the same day $(P<0.05)$. Different capital letters in the same column (A, B, C, D) indicate the difference in the same group on different days $(P<0.05)$. CG: Control. NHCG: Normal hydrolysate coated group. UHCG: Ultrasound-assisted hydrolysate coated group, *: Not analyzed

\section{Indicators of fish degradation and resistance to fat oxidation}

The degradation of protein and non-nitrogen components by factors such as microbiological activities of bacteria, enzymatic autolysis, lipid, and oxidation of proteins leads to the accumulation of organic amines, generally known as TVB$\mathrm{N}$. With the storage period, the TVB-N value increases depending on this accumulation. TVB-N contents are toxic and cause color and taste changes in the texture, thus affecting the acceptability in consumption (Cao et al., 2019). Changes in TVB-N, TBA, and TMA values of smoked bonito fillets that were coated and stored at $+4{ }^{\circ} \mathrm{C}$, are shown in Table 2.

TVB-N of fresh bonito fillet was determined as $15.56 \pm$ $0.50 \mathrm{mg} / 100 \mathrm{~g}$. This value has increased statistically in all groups starting from the first day of the storage $(P<0.05)$. Increases were significantly higher in CG than NHCG and UHCG ( $P<0.05)$. It exceeded the acceptability limit by reaching $41.88 \pm 0.35 \mathrm{mg} / 100 \mathrm{~g}$ for CG on the 39th day of storage, $43.12 \pm 0.35 \mathrm{mg} / 100 \mathrm{~g}$ and $42.68 \pm 0.30 \mathrm{mg} / 100 \mathrm{~g}$ for the NHCG and UHCG, on the $60^{\text {th }}$ day of the storage, respectively. In addition to improved protective effects supplied by the combination of low moisture content by the effect of drying, salt content, and sawdust active ingredients, it can be said that coating materials could delay microbial deterioration and oxidation and made NHCG and UHCG's shelf lives longer than CG. The differences in TVB-N values of NHCG and UHCG were not statistically significant $(P>0.05)$. Yu et al., (2021) determined the effects of ultrasound-assisted chitooligosaccharide (COS-UA) and chitooligosaccharide (COS) coating on grass carp fillets during cold storage. Researchers stated that TVB-N values of the fillets increased slowly up to the 3rd day for each group, but this increase was not statistically important. TVB-N values of COS and COS-UA were lower than the control group (about 17-37 \%). TVB-N value of COS-UA was found lower than COS on the 6th day. The control group's TVB-N value reached the minimum limit $(11.39 \mathrm{mg} / 100 \mathrm{~g})$ on the 6th day, but this limit was exceeded by COS and COS-UA on the 9th and 12th days, respectively. This was explained by the effect of ultrasound application that could help to inhibit the deterioration. El-Obeid et al., (2018) observed the shelf-life of smoked eel fillets treated with chitosan and thyme oil using vacuum packaging (VP) at $4{ }^{\circ} \mathrm{C}$. They prepared smoked fillet groups as $S$ (control, smoked, no antimicrobials added), ST with added thyme EO, SC with added chitosan, and SCT with added chitosan and thyme EO. They reported increasing trends in TVB-N content of all groups of smoked ell fillets had during the storage. They calculated the TVB-N values of S, ST, SC and, SCT as $31.5 \mathrm{mg} \mathrm{N} / 100 \mathrm{~g}$ and $18.1,14.9$ and $13.1 \mathrm{mg} \mathrm{N} / 100 \mathrm{~g}$, respectively, on final days 35 and 42,49 of storage. These previous studies' results had shown similar trends with the present study that ultrasound-assisted and/or normal treatments of natural coatings extended the shelf life of fish fillets during cold storage by delaying the deterioration. In the present research preventive effect of coating materials with their antioxidant activities (determined in our previous research paper (Balcik Misir and Koral 2019a) resulted in a lower increase in the TBA values of NHCG and UHCG than 
CG. The TBA values of CG exceeded the consumable limit on the 33rd day of storage whereas, in the NHCG and UHCG, this limit was exceeded on the 60th day. As seen in Table 2, the TBA of UHCG was significantly lower than NHCG $(p<0.05)$. Higher antioxidant activity of UHCG could be effective on this result (Balcik Misir and Koral, 2019a). Noman et al., (2020) reported, "US (ultrasound) technique can play a promising role in the production of protein hydrolysates and the improvement of their antioxidant properties." El-Obeid et al., (2018) explained the lower TBA values in the treated SC, SCT eel samples as the high antioxidant activity of chitosan and thyme EO which could reduce the level of oxidation in the eel samples.

Table 2. Changes in TVB-N, TBA and, TMA parameters of smoked bonito fillets coated with fish protein hydrolysate during storage at $\left(4 \pm 1^{\circ} \mathrm{C}\right)$

\begin{tabular}{|c|c|c|c|c|}
\hline Days & Sample & $\begin{array}{l}\text { TVB-N } \\
\text { (mg/100g) }\end{array}$ & $\begin{array}{l}\text { TBA } \\
\text { (mg MA/kg) }\end{array}$ & TMA $(\mathrm{mg} / 100 \mathrm{~g})$ \\
\hline \multirow[t]{2}{*}{0} & $\begin{array}{l}\text { Fresh } \\
\text { Bonito fillets }\end{array}$ & $15.56 \pm 0.50$ & $0.46 \pm 0.06$ & $0.48 \pm 0.06$ \\
\hline & CG & $18.11 \pm 0.30^{\mathrm{a}_{\mathrm{A}}}$ & $1.18 \pm 0.06^{\mathrm{a}_{\mathrm{A}}}$ & $0.68 \pm 0.06^{a_{A}}$ \\
\hline \multirow[t]{3}{*}{1} & NHCG & $16.66 \pm 0.15^{b_{A}}$ & $0.92 \pm 0.06^{\mathrm{b}} \mathrm{A}$ & $0.56 \pm 0.04^{\mathrm{b}} \mathrm{A}$ \\
\hline & UHCG & $16.31 \pm 0.10^{b_{A}}$ & $0.86 \pm 0.08^{b} \mathrm{~A}$ & $0.54 \pm 0.04^{\mathrm{b}} \mathrm{A}$ \\
\hline & CG & $22.28 \pm 0.15^{a}$ & $2.72 \pm 0.12^{a_{B}}$ & $0.89 \pm 0.05 a_{B}$ \\
\hline \multirow[t]{3}{*}{6} & NHCG & $18.14 \pm 0.17 b_{B}$ & $1.54 \pm 0.08^{b_{B}}$ & $0.66 \pm 0.06^{b} \mathrm{~A}$ \\
\hline & UHCG & $18.68 \pm 0.15^{b_{B}}$ & $1.39 \pm 0.10 c_{B}$ & $0.60 \pm 0.04 \mathrm{~b}_{\mathrm{A}}$ \\
\hline & CG & $24.12 \pm 0.15^{\mathrm{a}} \mathrm{c}$ & $4.11 \pm 0.08^{a} \mathrm{C}$ & $1.02 \pm 0.10^{\mathrm{a}} \mathrm{C}$ \\
\hline \multirow[t]{3}{*}{12} & NHCG & $20.50 \pm 0.17 b^{b} c$ & $2.56 \pm 0.14^{b} \mathrm{c}$ & $0.86 \pm 0.04 b_{B}$ \\
\hline & UHCG & $20.28 \pm 0.15^{b} c$ & $2.24 \pm 0.06^{c} c$ & $0.78 \pm 0.08^{b_{B}}$ \\
\hline & CG & $27.88 \pm 0.17 a^{a}$ & $5.76 \pm 0.14 a_{D}$ & $1.68 \pm 0.06^{a_{D}}$ \\
\hline \multirow[t]{3}{*}{16} & NHCG & $23.48 \pm 0.17 b_{D}$ & $3.48 \pm 0.10^{\mathrm{b}} \mathrm{D}$ & $1.18 \pm 0.06^{b} c$ \\
\hline & UHCG & $23.08 \pm 0.15^{b} b$ & $3.25 \pm 0.08 c_{D}$ & $1.09 \pm 0.04^{b} c$ \\
\hline & CG & $30.12 \pm 0.30^{\mathrm{a}} \mathrm{E}$ & $6.35 \pm 0.14 \mathrm{a}_{\mathrm{E}}$ & $2.08 \pm 0.10^{a_{E}}$ \\
\hline \multirow[t]{3}{*}{21} & NHCG & $26.18 \pm 0.30^{\mathrm{b}} \mathrm{E}$ & $4.56 \pm 0.06^{b_{E}}$ & $1.52 \pm 0.08^{\mathrm{b}} \mathrm{D}$ \\
\hline & UHCG & $26.12 \pm 0.15^{b}$ & $4.08 \pm 0.12^{c_{E}}$ & $1.38 \pm 0.10^{b} \mathrm{D}$ \\
\hline & CG & $33.88 \pm 0.17 a_{F}$ & $7.28 \pm 0.10^{a_{\mathrm{F}}}$ & $2.72 \pm 0.06^{a_{F}}$ \\
\hline \multirow{3}{*}{33} & NHCG & $29.26 \pm 0.10^{b} F$ & $5.02 \pm 0.08^{b_{F}}$ & $1.82 \pm 0.10^{b_{E}}$ \\
\hline & UHCG & $29.18 \pm 0.15^{b} F$ & $4.70 \pm 0.06 c_{F}$ & $1.66 \pm 0.08^{b} \mathrm{E}$ \\
\hline & CG & $41.88 \pm 0.35{ }^{\mathrm{a}} \mathrm{G}$ & $8.03 \pm 0.08^{a_{G}}$ & $3.62 \pm 0.08^{a_{G}}$ \\
\hline \multirow[t]{3}{*}{39} & NHCG & $31.78 \pm 0.15^{b} G$ & $5.50 \pm 0.12^{\mathrm{b}} \mathrm{G}$ & $2.24 \pm 0.06^{b_{F}}$ \\
\hline & UHCG & $31.66 \pm 0.30^{b_{G}}$ & $5.08 \pm 0.10{ }^{c} G$ & $2.16 \pm 0.10^{b} F$ \\
\hline & CG & * & * & * \\
\hline \multirow[t]{3}{*}{50} & NHCG & $34.28 \pm 0.35 \mathrm{a}_{\mathrm{H}}$ & $5.98 \pm 0.10^{a_{H}}$ & $2.64 \pm 0.06^{a_{G}}$ \\
\hline & UHCG & $33.96 \pm 0.17 \mathrm{a}_{\mathrm{H}}$ & $5.38 \pm 0.12^{b} \mathrm{H}$ & $2.56 \pm 0.10^{a_{G}}$ \\
\hline & CG & * & * & * \\
\hline \multirow[t]{2}{*}{60} & NHCG & $43.12 \pm 0.35 a_{1}$ & $7.19 \pm 0.16^{a_{1}}$ & $3.06 \pm 0.08 a_{H}$ \\
\hline & UHCG & $42.68 \pm 0.30 a_{1}$ & $6.48 \pm 0.12^{b_{l}}$ & $2.88 \pm 0.10^{a_{H}}$ \\
\hline
\end{tabular}

Different lowercase letters $(a, b, c)$ in the same column indicate the difference between the groups on the same day $(P<0.05)$. Different capital letters in the same column ( $A, B, C, D)$ indicate the difference in the same group on different days ( $P$ <0.05). CG: Control. NHCG: Normal hydrolysate coated group. UHCG: Ultrasound-assisted hydrolysate coated group, *: Not analyzed
Triethylamine oxide forms TMA by the enzymatic activity of bacteria, which is responsible for the unpleasant fishy odor (Olafsdóttir et al.,1997). The TMA values of all studied groups were well below the consumable limits throughout the entire store (Table 2). This situation could be due to both brining process used by the nature of the smoking process and the antioxidant and antimicrobial activities of the smoking material, and the temperature applied during the smoking. The microbial growth in the product was restricted under the influence of salt and temperature with decreasing moisture content. But lower TMA values of NHCG and UHCG than CG could be explained by coating materials used in these products. Coatings might have formed a protective layer on the surface of the fillets that prevented the passage of gasses, moisture, and microorganisms through the fillets and protected them. But similar to TVB-N, TMA values of NHCG and UHCG were not statistically different throughout the storage. There have been stated in some previous researches that edible coating materials of both vegetable and animal origins have shown antioxidant and antimicrobial effects in smoked fish species resulting in quite a long shelf life compared to control groups (El-Obeid et al., 2018; Martínez et al., 2018).

\section{Changes in the microbiological structure}

The changes in the number of TAMB, TAPB, total coliform, and total mold and yeast in coated smoked bonito fillets are presented in Table 3. The initial TAMB, TAPB, coliform bacteria, and yeast/mold counts for fresh bonito fillets were $3.18 \pm 0.10,2.94 \pm 0.08,<1.47$, and $<1.47$, respectively.

The counts have decreased with the effect of the smoking process on the $1^{\text {st }}$ day of storage, then started to increase. CG became inconsumable in terms of TAMB and TAPB loads on the 39th day, while in NHCG and UHCG, these loads have remained within the limits of consumable until the end of the storage period. TAPB loads of NHCG and UHCG have exceeded the consumable limits on the 60th day of storage. Although initially very low, there was an increase observed in the counts of coliform bacteria in CG on the 16th day of storage. Although the counts of yeast and mold increased in the $C G$ on the $12^{\text {th }}$ day, these counts increased on the $33^{\text {rd }}$ day of storage in NHCG and UHCG. Yeast and molds are not found in normal flora in fish. The contamination can occur during catching, processing, from nets, tools, and other materials (Carrion-Granda et al., 2018). As seen from Table 3 , similar to coliform bacteria, there was an increase occurred in the counts of yeasts and molds. Previous studies supported that protein-based edible films can extend the shelf life of the product by suppressing microbial growth (Xiong et al., 2021; Dinika et al., 2020). Choulitoudi et al. (2017) applied plant extracts enriched with rosemary extracts as a coating material in the preservation of smoked ell. They expressed that the coating material shoved antimicrobial activity and prevented bacterial growth compared to the control group. Enriched the stability of smoked ell antimicrobial points. 
Table 3. Changes in microbiological counts of smoked bonito fillets coated with fish protein hydrolysate during storage at $\left(4 \pm 1^{\circ} \mathrm{C}\right)$

\begin{tabular}{|c|c|c|c|c|c|}
\hline \multicolumn{6}{|c|}{ Total Aerobic Bacteria (log CFU/g) } \\
\hline Days & Givups & Mesophilic & Psychrophilic & Coliform Bacteria & Yeast and Mold \\
\hline \multirow[t]{2}{*}{0} & $\begin{array}{l}\text { Fresh } \\
\text { Bonito Fillets }\end{array}$ & $3.18 \pm 0.10$ & $2.94 \pm 0.08$ & $<1.47$ & $<1.47$ \\
\hline & CG & $2.44 \pm 0.06^{\mathrm{a}} \mathrm{A}$ & $2.46 \pm 0.04 \mathrm{a}_{\mathrm{A}}$ & $<1.47$ & $<1.47$ \\
\hline \multirow[t]{3}{*}{1} & NHCG & $2.36 \pm 0.04 \mathrm{a}_{\mathrm{A}}$ & $2.42 \pm 0.06^{\mathrm{a}_{\mathrm{A}}}$ & $<1.47$ & $<1.47$ \\
\hline & UHCG & $2.32 \pm 0.08^{\mathrm{a}_{\mathrm{A}}}$ & $2.40 \pm 0.06^{a_{A}}$ & $<1.47$ & $<1.47$ \\
\hline & CG & $2.68 \pm 0.06^{\mathrm{a}_{\mathrm{B}}}$ & $2.78 \pm 0.04 a_{B}$ & $<1.47$ & $<1.47$ \\
\hline \multirow[t]{3}{*}{6} & NHCG & $2.40 \pm 0.08^{\mathrm{b}} \mathrm{A}$ & $2.48 \pm 0.08^{\mathrm{b}} \mathrm{A}$ & $<1.47$ & $<1.47$ \\
\hline & UHCG & $2.38 \pm 0.04^{\mathrm{b}} \mathrm{A}$ & $2.40 \pm 0.10^{\mathrm{b}} \mathrm{A}$ & $<1.47$ & $<1.47$ \\
\hline & CG & $3.18 \pm 0.10^{a_{a}}$ & $3.48 \pm 0.08^{\mathrm{a}} \mathrm{C}$ & $<1.47$ & $1.58 \pm 0.06_{A}$ \\
\hline \multirow[t]{3}{*}{12} & NHCG & $2.68 \pm 0.10^{\mathrm{b}} \mathrm{B}$ & $2.90 \pm 0.12^{\mathrm{b}} \mathrm{B}$ & $<1.47$ & $<1.47$ \\
\hline & UHCG & $2.70 \pm 0.14^{b_{B}}$ & $2.86 \pm 0.10^{b_{B}}$ & $<1.47$ & $<1.47$ \\
\hline & CG & $3.76 \pm 0.10^{\mathrm{a} D}$ & $4.25 \pm 0.08^{a} \mathrm{D}$ & $1.62 \pm 0.12_{\mathrm{A}}$ & $1.98 \pm 0.08_{B}$ \\
\hline \multirow[t]{3}{*}{16} & NHCG & $3.12 \pm 0.12^{b} \mathrm{c}$ & $3.48 \pm 0.06^{b} \mathrm{c}$ & $<1.47$ & $<1.47$ \\
\hline & UHCG & $3.04 \pm 0.10^{b} \mathrm{c}$ & $3.40 \pm 0.14^{b} c$ & $<1.47$ & $<1.47$ \\
\hline & CG & $4.63 \pm 0.06^{a_{E}}$ & $5.18 \pm 0.06^{a_{E}}$ & $1.98 \pm 0.04_{B}$ & $2.38 \pm 0.10 D$ \\
\hline \multirow[t]{3}{*}{21} & NHCG & $3.72 \pm 0.10^{b} \mathrm{D}$ & $4.12 \pm 0.10^{\mathrm{b}} \mathrm{D}$ & $<1.47$ & $<1.47$ \\
\hline & UHCG & $3.60 \pm 0.08^{b} \mathrm{D}$ & $4.02 \pm 0.08^{b} \mathrm{D}$ & $<1.47$ & $<1.47$ \\
\hline & CG & $5.20 \pm 0.08^{\mathrm{a}_{\mathrm{F}}}$ & $6.40 \pm 0.06^{\mathrm{a}_{\mathrm{F}}}$ & $2.28 \pm 0.06^{\mathrm{a}} \mathrm{C}$ & $2.88 \pm 0.06^{a_{\mathrm{E}}}$ \\
\hline \multirow[t]{3}{*}{33} & NHCG & $4.52 \pm 0.10^{\mathrm{b}} \mathrm{E}$ & $4.96 \pm 0.10^{\mathrm{b}} \mathrm{E}$ & $1.62 \pm 0.04^{\mathrm{b}} \mathrm{A}$ & $1.52 \pm 0.04^{\mathrm{b}} \mathrm{A}$ \\
\hline & UHCG & $4.38 \pm 0.08{ }^{\mathrm{C}} \mathrm{E}$ & $4.80 \pm 0.12^{\mathrm{b}} \mathrm{E}$ & $1.58 \pm 0.08^{\mathrm{b}} \mathrm{A}$ & $1.50 \pm 0.02^{\mathrm{b}} \mathrm{A}$ \\
\hline & CG & $6.32 \pm 0.06^{\mathrm{a}} \mathrm{G}$ & $7.30 \pm 0.12^{\mathrm{a} D}$ & $2.82 \pm 0.10 \mathrm{a}^{\mathrm{D}}$ & $3.26 \pm 0.12^{\mathrm{a}_{\mathrm{F}}}$ \\
\hline \multirow[t]{3}{*}{39} & NHCG & $4.90 \pm 0.08^{\mathrm{b}} \mathrm{F}$ & $5.36 \pm 0.06^{b_{F}}$ & $1.88 \pm 0.08^{b_{B}}$ & $1.72 \pm 0.06^{b_{B}}$ \\
\hline & UHCG & $4.96 \pm 0.12^{\mathrm{b}} \mathrm{F}$ & $5.24 \pm 0.10^{\mathrm{b}} \mathrm{F}$ & $1.80 \pm 0.06^{b_{B}}$ & $1.70 \pm 0.08^{b_{B}}$ \\
\hline & CG & * & * & * & * \\
\hline \multirow[t]{3}{*}{50} & NHCG & $5.22 \pm 0.06^{\mathrm{a}} \mathrm{G}$ & $5.98 \pm 0.10 \mathrm{a}_{\mathrm{G}}$ & $2.18 \pm 0.06^{\mathrm{a}} \mathrm{C}$ & $1.98 \pm 0.04 \mathrm{a}_{C}$ \\
\hline & UHCG & $5.16 \pm 0.08^{\mathrm{a}} \mathrm{G}$ & $5.92 \pm 0.08 \mathrm{a}_{\mathrm{G}}$ & $2.12 \pm 0.08^{\mathrm{a}} \mathrm{C}$ & $1.90 \pm 0.06^{\mathrm{a}} \mathrm{C}$ \\
\hline & CG & * & * & * & * \\
\hline \multirow[t]{2}{*}{60} & NHCG & $5,72 \pm 0,08 \mathrm{a}_{\mathrm{H}}$ & $6,82 \pm 0,10 a_{H}$ & $2,42 \pm 0,06^{a} C$ & $2,22 \pm 0,06^{a_{D}}$ \\
\hline & UHCG & $5,60 \pm 0,10^{a} \mathrm{H}$ & $6,68 \pm 0,06 a_{H}$ & $2,36 \pm 0,04 a_{C}$ & $2,16 \pm 0,08^{a_{D}}$ \\
\hline
\end{tabular}

Different lowercase letters $(a, b, c)$ in the same column indicate the difference between the groups on the same day $(P<0.05)$. Different capital letters in the same column $(A, B, C, D)$ indicate the difference in the same group on different days $(P<0.05)$. CG: Control. NHCG: Normal hydrolysate coated group. UHCG: Ultrasound-assisted hydrolysate coated group, *: Not analyzed

\section{CONCLUSION}

Normal and ultrasound-assisted protein hydrolysates were produced enzymatically. Resultant hydrolysates were used as a bioactive coating on smoked bonito fillets for preservation. Ultrasound technique could have a promising potential to get increased antioxidant/antimicrobial activities and improved physical, chemical properties for protein hydrolysates. The overall results clearly illustrated that both protein hydrolysates here-produced are a well-defined approach that could extend the shelf life of smoked fish fillets. Both coatings inhibited the microbiological growth and significant decreases obtained in the TVB-N, TBA, and TMA values. As a result, it is obvious that ultrasound-assisted protein hydrolysate produced from fish by-products may be used as a coating material with good antioxidant activity. However, ultrasonic applications in protein hydrolysate production are still in their early stages. It requires many future investigations to implement this technology on an industrial scale and explain the effect of ultrasound on the properties of protein hydrolysates.

\section{ACKNOWLEDGEMENTS}

This study is a part of the $\mathrm{PhD}$ thesis of Gülsüm Balçık Mısır, the author thanks to Directorate of Central Fisheries Research Institute for giving this opportunity, to perform this study during the work. 


\section{REFERENCES}

Balçik Misir, G., Tufan, B. \& Köse, S. (2014). Monthly variation of total lipid and fatty acid contents of Atlantic bonito, Sarda sarda (Bloch, 1793) of Black Sea. International Journal of Food Science and Technology, 49, 2668-2677. DOI: 10.1111/ijfs.12578

Balcik Misir, G. \& Koral, S. (2019a). Effects of ultrasound treatment on biochemical, structural, functional properties and antioxidant activity of protein hydrolysate of rainbow trout (Oncorhynchus mykiss) by-products. Italian Journal of Food Science, 31, 2, DOI: 10.14674/IJFS-1218

Balcik Misir, G. \& Koral S. (2019b). Effects of edible coatings based on ultrasound-treated fish proteins hydrolysate in quality attributes of chilled bonito fillets, Journal of Aquatic Food Product Technology, 28, 9991012. DOI: $10.1080 / 10498850.2019 .1681572$

Bell, C., Neaves, P. \& Willams, A.P. (2005). Food Microbiology and Laboratory Practice. Blackwell, Oxford, UK, $324 \mathrm{~s}$.

Boland, F.E. \& Paige, D.D. (1971). Collaborative study of a method for the determination of trimethylamine nitrogen in fish. J. AOAC 4(3), 725-727.

Cao, L., Sun, G., Zhang, C., Liu, W., Li, J. \& Wang, L. (2019). An Intelligent Film Based on Cassia Gum Containing Bromothymol Blue-Anchored Cellulose Fibers for Real-Time Detection of Meat Freshness, Journal of Agricultural and Food Chemistry 67 (7), 2066-2074. DOI: $10.1021 /$ acs.jafc.8b06493

Carrion-Granda, X., Fernandez-Pan, I., Rovira, J. \& Mate, J. I. (2018). Effect of Antimicrobial Edible Coatings and Modified Atmosphere Packaging on the Microbiological Quality of Cold Stored Hake (Merluccius merluccius) Fillets. Journal of Food Quality, 2018, 1-12.

Castañeda-López, G.G., Ulloa, J.A., Rosas-Ulloa, P., Ramírez-Ramírez, J.C., Gutiérrez-Leyva, R. Carrillo, Y.S. \& Ulloa-Rangel, B.E., (2021). Ultrasound use as a pretreatment for shrimp (Litopenaeus vannamei) dehydration and its effect on physicochemical, microbiological, structural, and rehydration properties. Journal of Food Processing and Preservation, 45:e15366.) DOI: 10.1111/jfpp.153662015

Choulitoudi, E., Ganiari, S., Tsironi, T., Ntzimani, A., Tsimogiannis, D., Taoukis, P. \& Oreopoulou, V. (2017). Edible coating enriched with rosemary extracts to enhance oxidative and microbial stability of smoked eel fillets. Food Pack. Shelf Life. 12: 107-113.

Codex Alimentarius (2013). Standard for smoked fish, smoke-flavoured fish and smoke-dried fish - (311-2013). Rome.

Dhiman, A., Suhag, R., Chauhan, D.S., Thakur, D., Chhikara, S. \& Prabhakar, P.K. (2021). Status of beetroot processing and processed products: Thermal and emerging technologies intervention. Trends in Food Science \& Technology, 114, 443-458, DOI: 10.1016/j.tifs.2021.05.042

Dinika, I., Verma, K.D., Balia, R., Utama, G. L. \& Patel, A.R. (2020). Potential of cheese whey bioactive proteins and peptides in the development of antimicrobial edible film composite: A review of recent trends, Trends in Food Science \& Technology, 103, 57-67, DOI: 10.1016/j.tifs.2020.06.017

El-Obeid, T., Hany, M. Yehia-Hercules, S., Louisa, L., Maria, I., Tsiraki, I. \& Savvaidis, N. (2018). Shelf-life of smoked eel fillets treated with chitosan or thyme oil. International Journal of Biological Macromolecules, 114(4), 578-583. DOI: 10.1016/j.ijbiomac.2018.03.125

FAO, (2020). Food loss and waste must be reduced for greater food security and environmental sustainability. Citation address: http://www.fao.org/news/story/en/item/1310271/icode/ (5.05.2021).

Favetto, G., Resnik, S., Chirife, J. \& Fontan, C.F. (1983). Statistical Evaluation of Water Activity Measurements Obtained with the Vaisala Humicap Humidity Meter. Journal of Food Science, 48: 534-538. DOI: 10.1111/j.1365-2621.1983.tb10783.x

Hajfathalian, M., Jorjani, S. \& Ghelichi, S. (2020). Characterization of fish sausage manufactured with combination of sunflower oil and fish oil stabilized with fish roe protein hydrolysates. Journal of Food Science Technology, 57, 1439-1448. DOI: 10.1007/s13197-019-04179-6
Jimenez, L.R, Paola, A.S, Yeannes, I.M. \& Czerner, M. (2020). Cold smoking of Lebranche mullet (Mugil liza): Physicochemical, sensory, and microbiological evaluation. Food Science and Technology International. DOI: 10.1177/1082013220951674

Karnjanapratum, S. \& Benjakul, S. (2020). Asian bullfrog (Rana tigerina) skin gelatin extracted by ultrasound-assisted process: Characteristics and invitro cytotoxicity, International Journal of Biological Macromolecules, 148, 391-400, DOI: 10.1016/j.ijbiomac.2020.01.150

Koral, S. (2006). Investigating the quality changes of raw and smoked pacific mullet (Mugil so-iuy, basilewski, 1855) and bonito (Sarda sarda, Bloch, 1838) at ambient and refrigerated temperatures. Master Thesis. Karadeniz Technical University, Institute of Applied Science, Trabzon, Türkiye, $76 \mathrm{pp}$.

Koral, S. (2012). Determination of biogenic amine contents and factors affecting their formation in the traditional fish products in Turkey. PhD. Thesis. Karadeniz Technical University, Institute of Applied Science, Trabzon, Türkiye, $231 \mathrm{p}$.

Koral, S. \& Köse, S. (2018). The Effect of Using Frozen Raw Material and Different Salt Ratios on the Quality Changes of Dry Salted Atlantic Bonito (Lakerda) at Two Storage Conditions. Food and Health, 4(4), 213-230. DOI: 10.3153/FH18022

Kramarenko, T., Roasto, M., Keto-Timonen, R., Mäesaar, M., Meremäe, K., Kuningas, M., Horman, A. \& Korkeala, H. (2016). Listeria monocytogenes in ready-to-eat vacuum and modified atmosphere packaged meat and fish products of Estonian origin at retail level. Food Control, 67, 48-52. DOI: 10.1016/j.foodcont.2016.02.034

Lerfall, J. \& Hoel, S. (2021). Effects of salting technology and smoking protocol on yield and quality of hot-smoked Atlantic salmon (Salmo salar L.). Journal of Food Processing and Preservation, 45:e15064. DOI: $10.1111 /$ jppp. 15064

Leroi, F. \& Joffraud, J.J. (2000). Salt and smoke simultaneously affect chemical and sensory quality of cold-smoked salmon during $5{ }^{\circ} \mathrm{C}$ storage predicted using factorial design. Journal of Food Protection, 63 (9):1222-1227.

Lougovois, V.P. \& Kyrana, V.R. (2005). Freshness quality and spoilage of chill-stored fish. In A. P. Riley (Ed.) Food Policy, Control and Research, Freshness Quality and Spoilage of Chill-Stored Fish (pp. 35-86) New York: Nova Science Publishers, Inc.

Lücke, F. \& Geidel, W. (1935). Determination of volatile basic nitrogen in fish as a measure of their freshness. Zeitschrift für Lebensmittel Untersuchung und Forschung, 70, 441-458.

Martínez, O., Salmerón, J., Epelde, L., Vicente, M.S. \& de Vega, C. (2018). Quality enhancement of smoked sea bass (Dicentrarchus labrax) fillets by adding resveratrol and coating with chitosan and alginate edible films, Food Control, 85, 168-176, DOI: 10.1016/j.foodcont.2017.10.003

Muñoz, I., Guàrdia, M.D., Arnau, J., Dalgaard, P., Bover, S., Fernandes, J.O., Monteiro, C., Cunha, S.C., Gonçalves, A., Nunes, M.L. \& Oliveira, H. (2020). Effect of the sodium reduction and smoking system on quality and safety of smoked salmon (Salmo salar), Food and Chemical Toxicology, 143,111554. DOI: 10.1016/j.fct.2020.111554

Noman, A., Qixing, J., Xu, Y., Abed, S.M., Obadi, M., Ali, A.H., AL-Bukhaiti, W.Q. \& Xia, W. (2020). Effects of ultrasonic, microwave, and combined ultrasonic-microwave pretreatments on the enzymatic hydrolysis process and protein hydrolysate properties obtained from Chinese sturgeon (Acipenser sinensis). Journal of Food Chemistry. 44:e13292. DOI: $10.1111 / \mathrm{jbc} .13292$

Olafsdóttir, G., Martinsdóttir, E., Oehlenschläger, J., Dalgaard, P., Jensen, B., Undeland, I., Mackie, I.M., Henehan, G., Nielsen, J. \& Nilsen, H. (1997). Methods to evaluate fish freshness in research and industry. Trends in Food Science \& Technology 8, 258-265. 
Pedro, S.\& Nunes, M.L. (2019). Reducing salt in seafood products. In C. Beeren, K. Groves, P.M. Titoria (Eds.), Reducing Salt in Foods, Woodhead Publishing Limited, Cambridge (2019), pp. 185-211.

Rodriguez-Turienzo, L., Cobos, A., Moreno, V., Caride, A., Vieites, J.M. \& Diaz, O. (2011). Whey protein-based coatings on frozen Atlantic salmon (Salmo salar): Influence of the plasticiser and the moment of coating on quality preservation. Food Chemistry, 128, 187-194.

Rohani, A.C., Arup, M.J. \& Zahrah, T. (2010). Brining parameters for the processing of smoked river carp (Leptobarbus hoevenii). Journal of the Science of Food and Agriculture, 38(1), 51-61.

Sokal, R.R. \& Rohlf, J. (1987). Introduction to biostatistics, New York, Freeman, $2^{\text {nd }} \mathrm{Ed} .363$ p.

Sone, I., Skåra, T. \& Olsen, S. H. (2019). Factors influencing post-mortem quality, safety and storage stability of mackerel species: A review. European Food Research and Technology, 245, 775-791.

Tarladgis, B.G., Watts, B.M., Younathan, M.T. \& Dugan, J.R. (1960). A distillation method for the quantitative determination of malonaldehyde in racid foods. Journal of American Oil Chemist's Society, 37, 44-48.

Valø, T., Jakobsen, A. N. \& Lerfall, J. (2020). The use of atomized purified condensed smoke (PCS) in cold-smoke processing of Atlantic salmon Effects on quality and microbiological stability of a lightly salted product, Food Control, 112, 107155. DOI: 10.1016/j.foodcont.2020.107155
Wen, C., Zhang, J., Zhang, H., Dzah, C. S., Zandile, M., Duan, Y., ... Luo, X (2018). Advances in ultrasound assisted extraction of bioactive compounds from cash crops-A review. Ultrasonics Sonochemistry, 48 538-549.

Xiong, Y., Kamboj, M., Ajlouni, S. \& Fang, Z. (2021). Incorporation of salmon bone gelatine with chitosan, gallic acid and clove oil as edible coating for the cold storage of fresh salmon fillet, Food Control, 125, 107994.

DOI: 10.1016/j.foodcont.2021.107994

Yu, D., Zhao, W., Yang, F., Jiang, Q., Xu, Y. \& Xia, W. (2021). A strategy of ultrasound-assisted processing to improve the performance of bio-based coating preservation for refrigerated carp fillets (Ctenopharyngodon idellus), Food Chemistry, 345, 128862

DOI: 10.1016/j.foodchem.2020.128862

Zhou, C., Okonkwo, C.E., Inyinbor, A.A., Yagoub, A.E.A. \& Olaniran, A.F. (2021) Ultrasound, infrared and its assisted technology, a promising tool in physical food processing: A review of recent developments, Critical Reviews in Food Science and Nutrition. DOI: 10.1080/10408398.2021.1966379

Zink, F., Kratzer, W., Schmidt, S., Oeztuerk, S., Mason, R.A., Porzner, M. Klaus. J,, Haenle, M.M. \& Graeter, T. (2016). Comparison of two highend ultrasound systems for contrast-enhanced ultrasound quantification of mural microvascularity in Crohn's disease. Ultraschall in der Medizin, $37,74-81$ 